\title{
CLUBE DE LEITURA DESIGUAIS: A EXPERIÊNCIA DE UMA COMUNIDADE DE LEITORES
}

\author{
Rita de Cassia Brêda M. Lima ${ }^{1}$
}

\section{Tessituras iniciais}

A formação de leitores vem sendo objeto de estudo de muitos pesquisadores de várias áreas do conhecimento, bem como tem inquietado educadores e bibliotecários. Assim, pensar a leitura como prática cultural é reconhecer sua importância e funcionalidade para além dos espaços escolares.

A leitura e, mais especificamente, a literatura, segundo Cândido (2004), “corresponde a uma necessidade universal que deve ser satisfeita sob pena de mutilar a personalidade, porque pelo fato de dar forma aos sentimentos e à visão do mundo, ela nos organiza, nos liberta do caos e, portanto, nos humaniza". Comungando com as ideias defendidas por Chartier (1994), Candido (2004), Petit (2009), Maria (2016) sobre a necessidade de investimento na formação de comunidade de leitores é que surgiu o Clube de Leitura Desiguais.

O Clube de Leitura se constitui na reunião de pessoas de interesses comuns, que, de forma organizada, combinam e definem em ler um mesmo livro, crônica, conto, ou outro material desejado, em um determinado período (pode ser semanal, mensal) e, em seguida, dialogar sobre o texto lido. A experiência aqui compartilhada refere-se ao Clube de Leitura Desiguais situado na Escola Estadual Juiz Jorge Faria Góes em parceria com o Núcleo de Leitura Multimeios da UEFS. Esta experiência se ancora no tripé ensino, pesquisa e extensão que vem balizando as ações dos membros do referido Núcleo e a criação do Clube de Leitura Desiguais. Tal ação integra as metas almejadas pela parceria UEFS e a Escola Estadual Juiz Jorge Faria Góes que visam a constituição de uma comunidade de leitores na escola, bem como pela defesa por ações de fomento e formação de leitores para além dos espaços formais de ensino, consequentemente, na luta pela instituição de políticas efetivas de formação de leitores.

O Clube de Leitura enquanto estratégia de formação de leitores tem como objetivos: Desenvolver práticas culturais com foco na formação de leitores; Criar uma comunidade de leitores; Compreender a literatura como direito universal; Ampliar o repertório literário dos alunos; Conhecer e dialogar sobre autores e obras e desenvolver ações de integração entre os alunos, tendo a literatura como eixo interdisciplinar e formativo.

A metodologia basilar do Clube de Leitura tem sido os Círculos de Leitura. São princípios dessa metodologia o diálogo, o respeito aos diferentes, a confiabilidade no potencial dos envolvidos e a escuta atenta e sensível. Os Círculos de Leitura são espaços formativos em que há um leitor-guia responsável pela escolha e mediação do processo de leitura. Após a leitura do texto ou obra, a palavra é franqueada aos presentes que, de forma livre e espontânea, socializa suas opiniões, compreensões, dúvidas, inquietações e descobertas propiciadas pela leitura do material previamente escolhido. Como ação que visa a formação de leitores, não há durante a realização dos encontros exigências de fala e ou participação, no entanto, cada membro solicita sua participação quando se sente confortável para tal, visto que as decisões são compartilhadas e assumidas a priori pelo grupo e, no dia agendado, sentados em círculos, cada membro apresenta aspectos da obra ou as considerações tecidas acerca do material lido.

\footnotetext{
${ }^{1}$ Professora Assistente do Departamento de Educação - Universidade Estadual de Feira de Santana - UEFS. E-mail: rbredalima@yahoo.com.br.
} 


\section{Diálogos sobre leitura...}

"No mundo contemporâneo, o conceito de verdadeira
democracia passa pelo decisivo investimento na
formação de leitores"

(MARIA, 2016, p. 27)

Muitos estudiosos da leitura e da formação de leitores já consensuaram sobre a importância da leitura para a formação plena do sujeito. Não cabe mais nos dias atuais a defesa por um aprendizado da leitura que limite os cidadãos apenas ao domínio superficial dos códigos linguísticos. As instituições formais do ensino precisam tomar para si a responsabilidade de garantir aos alunos o pleno domínio da leitura e da escrita. Ler e escrever com autonomia, desenvoltura e compreensão asseguram aos sujeitos uma melhor inserção no meio social. Aprende-se a ler para descobrir o mundo, para desvelar os fatos, para ampliar a sensibilidade e descobrir a si mesmos. Sendo assim, é cada vez mais urgente investir em práticas culturais de leitura que fomentem e propiciem uma ampla participação e empoderamento dos envolvidos.

Segundo Petit (2009, p. 7) "A leitura tem o poder de despertar em nós regiões que estavam até então adormecidas" e Cândido (2004) no seu texto $O$ direito à literatura afirma "Quer percebamos claramente ou não, o caráter de coisa organizada da obra literária torna-se um fator que nos deixa mais capazes de ordenar a nossa própria mente e sentimentos; e, em consequência, mais capazes de organizar a visão que temos do mundo" (p. 177). Portanto, reafirmam a potencialidade da leitura e da literatura como práticas culturais que podem corroborar para formação da autonomia, do senso crítico e da apropriação de saberes.

Investir em políticas e práticas efetivas para formação de leitores atende não apenas as exigências da verdadeira democracia como afirmou Maria (2016), mas, assegura-se também o usufruto pleno de um direito universal defendido por Candido (2004). Afirma Chartier (1994, p. 11) que "um texto só existe se houver um leitor para lhe dar um significado", portanto, é urgente forjar práticas leitoras que possibilitem aos sujeitos o mergulho nas palavras, nos textos e, a partir delas construam suas singulares compreensões. E foi com esse intuito que surgiu o Clube de Leitura Desiguais visando oportunizar novos espaços de encontros com a leitura e as obras literárias a fim de consolidar uma comunidade de leitores (CHARTIER, 1994).

Ao tratar a leitura numa perspectiva mais livre, autônoma e significativa para os alunos, o desafio é apresentar a leitura como prática social e cultural, portanto não limitada apenas ao contexto escolar.

\section{Alguns resultados...}

O Clube de Leitura surgiu no segundo semestre de 2016. Sua composição é formada por professores da rede estadual, professores da UEFS, graduandos do curso de Letras Vernáculas e Educação Física e alunos da Escola Estadual Juiz Jorge Faria Góes. Os encontros acontecem quinzenal ou mensalmente e primam pela análise e reflexão de obras da literatura clássica e contemporânea (nacional e estrangeira), bem como por fomentar o debate, o senso crítico, a autonomia e o poder de argumentação.

Como primeira experiência realizada por docentes da UEFS em parceria com a Escola Estadual Juiz Jorge Faria Góes - município de Feira de Santana, o Clube de Leitura vem implementando, ao longo da sua recente história, estratégias variadas para socialização e registros das vivências. Além de fazer parte da pesquisa de doutoramento de uma professora membro do Clube, já teve sua experiência divulgada em outras escolas da rede estadual e em 
eventos sobre bibliotecas escolares. Alguns resultados significativos tem sido a ampliação do número de participantes, atualmente o Clube conta com aproximadamente trinta membros, assim como a decisão por aprofundar autores clássicos da literatura brasileira, para além da socialização e resenha das leituras individuais. São resultados parciais, mas já anunciam a relevância da articulação e estreitamento das relações entre a Universidade e a Educação Básica.

\section{Tessituras finais}

A experiência com o Clube de Leitura é recente, mas é possível afirmar, a partir dos relatos dos integrantes, a importância não apenas da participação nos encontros do Clube, mas o significado formativo que esta prática leitora vem exercendo na história de leitura de cada sujeito, conforme podemos visualizar abaixo:

"Super ansiosa e com muita saudade de todos vocês. Louca para compartilhar minhas últimas leituras!"

"Já estava morrendo de saudades do Clube. Tenho que falar de Nárnia! Estou precisando deste café".

"Eu não tenho palavras para descrever o turbilhão de emoções que sinto quando estou com vocês. Esse clube é mais uma das maravilhosas memórias do Juiz Jorge que terei para sempre em minha lembrança. Amo muito tudo isso!"

"Mais um sonho realizado! Muito feliz por fazer parte dele!"

"No Clube de Leitura compartilhamos leituras, filmes e o melhor de tudo é que eu aprendo muito com cada um de vocês".

Os depoimentos revelam sobre os processos de aprendizagens, as relações afetivas e efetivas de encontro com a leitura e a literatura e a singularidade de uma experiência que deixará marcas para toda a vida. Portanto, reafirma-se que as práticas leitoras para além do espaço da sala de aula podem impactar nas vidas e nos processos formativos dos sujeitos envolvidos. É importante salientar que nesta comunidade de leitores, a biblioteca escolar não apenas sedia os encontros, mas seu acervo integra as ações e alimentam novas possibilidades de buscas por outras leituras.

\section{Referências}

CANDIDO, Antonio. Direito à Literatura. In: Vários escritos. Ouro sobre Azul, Rio de Janeiro, 2004.

CHARTIER, Roger. A ordem dos livros: leitores, autores e bibliotecas na Europa entre os séculos XIV e XVIII. Brasília: Editora Universidade de Brasília, 1994.

MARIA, Luzia de. O clube do livro: ser leitor, que diferença faz? São Paulo: Global, 2016.

PETIT, Michèle. Os jovens e a leitura: uma nova perspectiva. São Paulo: Editora 34, 2009. 